\title{
Media Quizizz Mampu Mengatasi Kejenuhan Siswa Dalam Pembelajaran Daring Pada Masa Pandemi Covid-19
}

\author{
Arif Ainur Rofiq ${ }^{1}$, Afifah Anjaina ${ }^{2}$, Romdloni ${ }^{3}$, Nur Ulwiyah ${ }^{3}$ \\ ${ }^{1,2}$ UIN Sunan Ampel Surabaya, \\ ${ }^{3}$ STKIP Nurul Huda OKU Timur \\ ${ }^{4}$ Universitas Pesantren Tinggi Darul Ulum Jombang \\ e-mail:arifainurrofiq@uinsby.ac.id, afifahanjainaw02@gmail.com, romdloni@stkipnurulhuda.ac.id, \\ nurulwiyah@fai.unipdu.ac.id
}

Received: 13 August 2021; Revised: 02 October 2021; Accepted: 14 December 2021

DOI: http://dx.doi.org/10.37905/aksara.8.1.101-112.2022

\begin{abstract}
The existence of the Covid-19 virus has triggered unrest in the community, especially in the education sector. During the COVID-19 pandemic, learning activities were carried out online, causing saturation in the teaching and learning process. Fortunately, in the industrial era 4.0 technology is growing rapidly, so teachers are also expected to keep up with existing technological changes. In this way, teachers also begin to innovate learning by involving technology. Although teachers have undoubted potential, there is a need for a buffer to maximize the potential for innovation in learning activities to avoid saturation. Participation in the role of learning media in overcoming student boredom is considered essential, one of which is the application of quizizz media in online learning. The purpose of this study was to find out how the application of quiziz media in overcoming student boredom in online learning during the covid19 pandemic. While this study uses descriptive qualitative methods and data collection in this study using structured interviews and students perception. Based on this research, it is concluded that first, quizizz learning media is a suitable media when applied in online learning by utilizing increasingly developing technology. Second, the application of quizizz media in online learning makes the problem of student boredom overcome and makes learning activities more effective, efficient and fun.
\end{abstract}

Keyword: learning media, quiziz, saturation, covid-19

\begin{abstract}
Abstrak
Adanya virus covid-19 memicu keresahan bagi masyarakat terutama pada sektor pendidikan. Selama masa pandemic covid-19 kegiatan pembelajaran dilaksanakan secara daring sehingga menyebabkan kejenuhan dalam proses belajar mengajar. Beruntungnya, di era industri 4.0 teknologi berkembang semakin pesat maka guru juga diharapkan mengikuti perubahan teknologi yang ada. Dengan begitu guru juga mulai menginovasi pembelajaran dengan melibatkan teknologi. Meskipun guru memiliki potensi yang tidak diragukan lagi namun perlu adanya penyangga guna memaksimalkan potensi inovasi kegiatan pembelajaran agar terhindar dari kejenuhan. Keikutsertaan peran media pembelajaran dalam mengatasi kejenuhan siswa sangat dianggap esensial, salah satunya dengan pengaplikasian media quizizz dalam pembelajaran daring. Tujuan dari penelitian ini dilaksanakan untuk mengetahui bagaimana pengaplikasian media quiziz dalam mengatasi kejenuhan siswa dalam pembelajran daring di masa pandemi covid-19. Sedangkan penelitian ini menggunakan metode kualitatif deskriptif serta pengumpulan data dalam penelitian ini menggunakan metode wawancara terstruktur dan students perception. Berdasarkan penelitian ini disimpulkan bahwa Pertama, media pembelajaran quizizz merupakan media yang cocok ketika diterapkan dalam pembelajaran daring dengan memanfaatkan teknologi yang semakin berkembang. Kedua, pengaplikasian media quizizz dalam pembelajaran daring menjadikan permasalahan kejenuhan siswa teratasi dan menjadikan kegiatan pembelajaran lebih efektif, efisien dan menyenagkan
\end{abstract}

Kata kunci: media pembelajaran daring, quizizz, kejenuhan, covid-19. 
AKSARA: Jurnal Ilmu Pendidikan Nonformal

P-ISSN 2407-8018 E-ISSN 2721-7310 DOI prefix 10.37905

Volume 08, (1), January 2022

http://ejurnal.pps.ung.ac.id/index.php/Aksara

\section{PENDAHULUAN}

Bermula dari Tiongkok memaparkan kasus pneumonia yang masih belum diketahui penyebabnya namun ketika diteliti pasien yang terpapar ada kaitannya dengan salah satu pasar seafood yang ada di Wuhan, Provinsi Hubei Tiongkok. Di Tiongkok pada mulanya pasien yang terindikasi acute respiratory distress syndrome hanya berjumah 44 namun dengan bertambahnya hari pasien yang terindikasi penyakit tersebut semakin meningkat hingga mencapai ribuan dan secara cepat meluas keseluruh penjuru dunia. Dunia kini lagi digemparkan dengan kasus virus corona. Coronavirus merupakan virus RNA tunggal positif yang berbentuk elips memiliki ukuran diameter 50-200m dan tidak memiliki segmen. Coronavirus dapat digolongkan pada ordo Nidovirales, familia Coronaviridae. Selain itu virus ini juga dapat memicu penyakit pada mamalia, burung dan manusia (Lam et al., 2015, pp. 1-3). Coronavirus jika terkena pada manusia menyebabkan infeksi saluran pernapasan yang dapat dikategorikan sebagai pemicu kematian.

Datangnya virus corona ke Indonesia menjadi suatu ancaman bagi masyarakat Indonesia. Beberapa sektor pun ikut terdampak dari munculnya virus corona tersebut. Mulai dari sektor kesehatan, perekonomian, pariwisata, hingga pendidikan. Seluruh aktivitas pun dibatasi guna menanggulangi penyebaran covid-19 yang semakin luas hingga Menteri Pendidikan dan Kebudayaan mengeluarkan kebijakan bahwa kegiatan pembelajaran saat pandemi diterapkan secara daring. Pembelajaran daring merupakan pembelajaran dengan memanfaatkan jaringan internet yang dihubungkan dengan komputer, laptop, maupun smartphone. Dalam UU Republik Indonesia Nomor 20 Tahun 2003 Mengenai Sistem Pendidikan Nasional pada bagian kesepuluh pasal 31 tentang pendidikan jarak jauh yang berbunyi (1) Pada seluruh jenjang, jalur, jenis pendidikan dapat menerapkan pendidikan jarak jauh. (2) Pendidikan jarak jauh mempunyai fungsi sebagai pemberi bantuan kepada masyarakat yang tidak dapat ikut serta dalam kegiatan belajar mengajar secara langsung atau tatap muka. (3) Pendidikan jarak jauh di diusahakan dalam bentuk, model, jangkauan dan tentunya perlu adanya dukungan dari media serta layanan pembelajaran, sistem penilaian yang dapat menjamin kelulusan sesuai standar nasional pendidikan. Sedangkan menurut pratiwi mengemukakan bahwa pembelajaran jarak jauh merupakan kegiatan belajar mengajar yang berlangsung dengan jarak jauh karena guru dan siswa berada pada suatau tempat yang terpisah, hanya bermodal kemandirian siswa serta dari media pembelajaran yang memadai dan mendukung (Pratiwi, 2020, pp. 30-46). Sedangkan Nurdin mengemukakan bahawa pendidikan jarak jauh ialah pepndidikan yang sifatnya terbuka dengan rancangan belajar yang tersususun dan sistem pembelajaran yang berlangsung tanpa adanya bertemu langsung maupun tatap muka (Nurdin, 2017).

Beruntungnya teknologi di era industri 4.0 semakin berkembang, berbagai platform tersedia sebagai penunjang dan sangat mengutungkan bagi kegiatan pembelajaran yang dilakukan secara daring sehingga dapat terciptanya pembelajaran yang menyenangkan (Darmalaksana et al., 2020, pp. 1-14). Terbukti perkembangan teknologi sangat mempengaruhi kegiatan pembelajaran, salah satunya dengan pengalikasian media pembelajaran daring. Dengan adanya media pembelajaran kegiatan belajar mengajar dapat terlaksana dengan menyenangkan, inovatif, kreatif. Serta mampu membantu meningkatnya keterampilan belajar, pemahaman dalam mencapai hasil belajar meskipun pengerjaan tugasnya dari rumah. 
Fenomena dilapangan memperlihatkan bahwa pelaksanaan kegiatan pembelajaran daring di masa pandemi tentu saja berbeda dengan pembelajaran luring. Terdapat beberapa perbedaan yang menjadi sorotan antara keduanya yaitu Pertama, adanya interaksi yang terbatas antara siswa dan guru dalam kegiatan pembelajaran, interaksi hanya melalui platform media online diantaranya Google form, Google Classroom, Whatsapp, Zoom, Google Meet, Schoology, Edmodo dsb sehingga pembelajaran tidak bisa terlaksana secara langsung maupun tatap muka. Kedua, tidak terciptannya suasana pembelajaran secara langsung, nyaman dan menyenangkan sehingga kegiatan pembelajaran tidak terlaksana secara efektif dan efisien. Tidak sedikit pula guru dalam kegiatan pembelajaran daring hanya dominan dengan pemberian materi, penugasan dan pelaporan kegiatan harian saja. Penerapan kegiatan pengajaran yang telah dijelaskan pada kalimat sebelumnya terkesan akan monoton dan membosankan.

Penerapan kegiatan pembelajaran yang telah dipaparkan memicu munculnya permasalahan baru seperti siswa kesulitan belajar, siswa kesulitan memahami pembelajaran, menurunnya minat siswa dalam mengikuti pembelajaran, serta siswa merasakan kejenuhan akibat pembelajaran yang monoton. Seluruh siswa merasa jenuh dengan pembelajaran daring, karena sekitar dua tahun lamanya sudah dilaksanakan secara daring. Kejenuhan belajar merupakan keadaan emosional seseorang saat merasa lelah dan bosan yang berkelanjutan sehingga menyebabkan munculnya rasa tidak bersemangat dalam melaksanakan kegiatan pembelajaran (Dewi et al., 2017, pp. 4-27). Kejenuhan sering kali muncul pada diri setiap siswa dalam berbagai macam bentuk seperti lelah fisik, lelah emosional, lelah kognitif, serta kurangnya apresiasi diri sebagai bentuk keterlibatan jangka panjang pada situasi tertentu (Rohman et al., 2018, pp. 13). Sedangkan Khaira mengemukakan bahwa kejenuhan belajar merupakan kegiatan belajar dalam batas waktu tertentu namun tidak mendapatkan hasil (Khaira, 2018, pp. 172200). Siswa yang mengalami kejenuhan merasa bahwa tidak ada peningkatan pengetahuan dan keterampilan yang didapatkan saat kegiatan pembelajaran. Sehingga menyebabkan munculnya perasaan sia-sia pada diri siswa karena telah mengikuti pembelajaran namun tidak mendapatkan pengaruh baik bagi dirinya.

Ketika kegiatan pembelajaran daring dilaksanakan tanpa adanya inovasi-inovasi lambat laun akan memicu kelelahan baik dari segi fisik, emosional, maupun kognitifnya. Kelelahan yang berkepanjanganakan berakibat pada kejenuhan siswa hingga tidak memiliki motivasi untuk mengikuti kegiatan pembelajaran. Dari banyaknya cara untuk mengatasi kejenuhan yang melanda siswa, salah satunya yaitu dengan cara mengaplikasikan media pembelajaran dalam kegiatan belajar mengajar. Media diartikan sebagai perantara yang digunakan sebagai penolong dari ketidakjelasan bahan pembelajaran yang disampaikan. Media pembelajaran merupakan seluruh bentuk peralatan yang dirancang khusus untuk menyampaikan informasi serta menumbuhkan interaksi antara guru maupun siswa (Yaumi, 2017, p. 7). Dalam kegiatan pembelajaran, media memiliki peranan penting yang mana telah dilakukan survei dan dibuktikan oleh Wang bahwa media pembelajaran berbasis digital mampu memicu dan meningkatkan minat serta motivasi siswa sebesar $80 \%$ dalam kegiatan pembelajaran. Sehingga kegiatan pembelajaran dapat berlangsung secara menyenagkan, efektif dan efisien dengan menggunakan media pembelajaran yang memadai. Selain berfungsi sebagai alat pendukung bagi guru dan alat pendukung bagi siswa untuk mempermudah siswa dalam memahami materi yang disampaikan oleh guru (Rafiuddin et al., 2017, pp. 148-155). 
Berbicara mengenai media pembelajaran beragam jenisnya mulai dari realia, teks, audio, visual, video, objek nyata, model, dan multimedia. Dari banyaknya ragam jenis media pembelajaran, salah satu media pembelajaran yang dapat meningkatkan minat dan semangat belajar yang menyenangkan, menarik, mempunyai sifat interaktif yang mengedepankan kekompakkan, komunikasi dan interaksi antara siswa yaitu media berbasis permainan online, terpenting pada permainan yang memiliki khayalan (fantasy), tantangan (challenges), rasa ingin tau (curiosity) (Irwan et al., 2019, p. 95). Keunggulan media berbasis permainan online dalam kegiatan pembelajaran lebih interaktif dan menyenangkan bahkan media berbasis permainan online juga mampu menstimulasi pertumbuhan karakter pada siswa (Irwan et al., 2019, p. 95). Dari banyaknya media pembelajaran berbasis permainan online yang mampu meningkatkan minat dan motivasi siswa yaitu media quiz interaktif. Dalam sebuah penelitian yang dilakukan oleh Untari mengatakan bahwa media quiz interaktif merupakan campuran antara metode tanya jawab, metode ceramah, serta penugasaan yang terkemas dalam sebuah permainan quiz (Sari et al., 2018, pp. 63-72). Permainan quiz dianggap mampu memberi kesempatan siswa untuk berpikir kreatif dan dianggap sebagai strategi guru yang diterapkan kepada siswa dengan memberikan pertanyaan-pertanyaan yang terdapat kaitannya dengan materi pembelajaran. Karena dengan pengaplikasian media quiz interaktif ini anggapan siswa seperti bermain, meskipun didalamnya terkemas pembelajaran yang dihubungkan dengan permainan sehingga pembelajaran terkesan tidak monoton dan menyenangkan.

Pada masa pandemi covid-19 SD Islam Kreatif Mutiara Anak Sholeh telah mengaplikasikan berbagai macam media permainan quiz salah satu dari media permainan quiz yang dapat digunakan guru dalam kegiatan pembelajaran yaitu quizizz yang mana dengan menggunakan media tersebut dapat menunjang kegiatan pembelajaran yang efektif, efisien, menyenangkan dan dapat diterapkan dalam pembelajaran walaupun siswa berada di rumah saja. Quizizz merupakan aplikasi pendidikan berbasis permainan online yang digunakan untuk membuat quiz interaktif yang dapat diakses oleh guru dan siswa dengan mudah. Aplikasi quizizz dimanfaatkan oleh guru sebagai media pembelajaran dan evaluasi dari kegiatan pembelajaran daring. Dengan aplikasi quizizz guru mudah dalam mengamati dan mengetahui meningkatnya konsentrasi serta motivasi siswa dalam pembelajaran secara daring di rumah. Berdasarkan pada permasalahan yang telah dipaparkan sebelumnya, tujuan dari penelitian ini untuk mengetahui bahwa media quizizz mampu mengatasi kejenuhan siswa dalam pembelajaran daraing di masa pandemic covid-19.

\section{METODE PENELITIAN}

Pada Kajian ini, peneliti dalam melaksanakan penelitian menggunakan pendekatan kualitatif jenis studi deskriptif. Penelitian kualitatif merupakan penelitian mempelajari seluruh macam hal atau seluruh macam peristiwa di dunia ini dalam lingkungannya yang alami, dengan tujuan untuk memperoleh pemahaman mengenai peristiwa tersebut berdasarkan penafsiran dari seseorang yang mengalami maupun menjalankan (Suwarsono, 2016, pp. 1-3). Sedangkan studi deskriptif merupakan suatu penelitian yang menunjukkan gambaran suatu kelompok orang tertentu maupun suatu fenomena keadaan tertentu (Soehartono, 2008, pp. 35). Sehingga dapat disimpulkan bahwa penelitian kualitatif dengan jenis studi deskriptif merupakan sebuah penelitian 
yang mempelajari suatu fenomena yang berasal pemaknaan seseorang dan dalam penelitian yang telah ditulis ini akan memberikan gambaran mengenai suatu fenomena tersebut dari sudut pandang yang diamati. Penelitian ini mengutamakan pada perolehan data yang akan di dapatkan secara mendetail, semakin detail dan lengkap data yang didapatkan maka kualitas penelitian kualitatif ini semakin baik pula.

Penelitian ini dilakukan di SD Islam Kreatif Mutiara Anak Sholeh yang terletak di Jl. Raya Pekarungan No.5, Desa Pekarungan, Kec. Sukodono, Kabupaten Sidoarjo, Jawa Timur 61258. Subyek pada penelitian ini yaitu seorang guru SD Islam Kreatif Mutiara Anak Sholeh yang bernama Muhfidatul Winda Hidayah, S.Pd. Teknik pengumpulan data yang peneliti lakukan dengan menggunakan metode observasi, wawancara terstruktur melalui zoom meeting, dokumentasi, serta studi pustaka. Peneliti juga melakukan wawancara tertutup yang diberikan kepada siswa kelas 6 SD Islam Kreatif Mutiara Anak Sholeh dan dikirim melalui google form, guna mengetahui timbal balik tentang penggunaaan media quizizz sebagai solusi kejenuhan siswa dari pembelajaran daring di masa pandemi. Setelah memperoleh seluruh data yang diperlukan, peneliti melaksanakan analisis data sesuai dengan teknik penelitian yang dilakukan Miles dan Huberman dalam Sugiyono diantaranya Pertama, teknik reduksi data. Dalam teknik reduksi, data yang telah disajikan dipilah-pilah terlebih dahulu dan dipilih mana yang terbilang penting serta urgent guna memudahkan penelitian dalam kegiatan penelitian. Kedua, penyajian data. Dalam teknik penyajian, data yang disajikan berupa suatu gambaran mengenai apa yang terjadi dan telah diteliti oleh peneliti. Ketiga, menarik kesimpulan yang mana isi dari kesimpulannya tentu berhubungan dengan tujuan penelitian.

\section{HASIL DAN PEMBAHASAN}

Pembelajaran dalam jaringan atau biasa disebut daring merupakan kegiatan pembelajaran yang dilaksanakan jarak jauh, tanpa bertemu langsung dan tatap muka secara fisik di lembaga pendidikan guna mencegah penyebaran virus covid-19. Beruntungnya era industry 4.0 telah memasuki belahan dunia yang mana di era ini teknologi informasi semakin berkembang hingga mengharuskan adanya perubahan digital. Kecondongan teknologi informasi menuju pada memanfaatkan teknologi komputer dan teknologi terkait dalam menggabungkan suatu gambar, grafik, data dan suara sehingga menjadikan sesuatu informasi yang saling keterkaitan serta luas dan lengkap. Informasi yang dihasilkan akan dipindahkan melalui suatu jaringan ke tempat lain dan menghasilkan hasil yang sama. Pengaplikasiannya berupa pemanfaatan aplikasi multimedia, aplikasi berbasis web melalui media internet, dan penerapan paket aplikasi terpadu (Warsita, 2011, pp. 86-90). Teknologi Pendidikan sudah lama dikenal dalam sekor pendidikan. Jika selama ini yang dapat memaksimalkan penguanaan teknologi digital ialah sekolah maupun Lembaga pendidikan yang memiliki sumber daya yang baik seperti guru mampu untuk mengoperasikan teknologi dan sarana prasarana yang mendukung, saat ini hal tersebut dapat dirasakan oleh hampir seluruh lembaga pendidikan. Banyaknya media pembelajaran membuat guru dapat menafaatkannya dalam proses belajar mengajar tanpa harus memperhatikan dimana letak keberadaannya serta pada tingkat pendidikan apapun. Namun demikian, dalam menjawab tantangan saat ini mengharuskan guru untuk mampu mengoperasikan teknologi dan menyampaikan materi melalui jarak jauh. 
Meskipun pembelajaran daring diterapkan pada era industri 4.0 yang mana dianggap sangat berkaitan dan cocok. Namun, dalam pelaksanaan pembelajaran daring masih memiliki kendala atau hambatan. Kendala dalam pembelajaran daring masih dirasakan oleh sebagian guru dan siswa. Terdapat beberapa kendala baik dari emosional siswa dan guru maupun kendala teknis. Kendala emosional yang dialami siswa, pembelajaran kurang efektif dan efisien serta tidak menyenangkan karena pembelajaran yang diterapkan hanya dominan dengan pemberian materi melalu whatsaap, penugasan sera pelaporan kegiatan harian dikirim melalui whatsapp berupa foto pengerjaan tugas, pdf, dsb. Kendala Teknis yang dialami siswa maupun guru disebabkan signal maupun ganguan layanan internet yang kurang mendukung dari berbagai latar belakang geografis, budaya, ekonomi, sosial serta pengalaman juga menyebabkan kegiatan pembelajaran tidak berjalan secara maksimal. Internet merupakan faktor pendukung yang harus ada demi kelancaran dalam kegiatan pembelajaran daring berlangsung.

Berdasarkan pengamatan dan wawancara mendetail kepada salah satu guru SD Islam Kreatif Mutiara Anak Sholeh yang bernama Ustadzah Muhfidatul Winda Hidayah, S.Pd melalui zoom meeting pada tanggal 26-30 Juli 2021, terkait pelaksanaan kegiatan pembelajaran daring di SD Islam Kreatif Mutiara Anak Sholeh telah mengusahakan dengan maksimal dalam mendukung kegiatan pembelajaran. Seluruh pihak sekolah terkhusus guru mata pelajaran telah terlibat aktif dalam mengoordinasi kepada orang tua siswa dan tentunya siswa untuk mengusahakan agar dapat menyesuaikan diri dengan platform yang telah disediakan serta orang tua dan siswa mampu mengatur waktu yang baik dalam kegiatan pembelajaran daring di masa pandemi covid-19. Sesuai dengan Setiawan bahwa kesepakatan yang telah disetujui oleh orang tua, siswa dan guru berguna untuk mengatasi kegagalan dalam pelaksanaan kegiatan pembelajaran daring bagi orang tua maupun siswa yang belum dapat mengakses platform saat kegiatan belajar mengajar berlangsung (Setiawan et al., 2019, pp. 167-173). Platform maupun media pembelajaran online dalam kegiatan pembelajaran secara daring sudah banyak tersedia, beragam macamnya, dan dapat diakses dengan mudah oleh siapapun secara berbayar maupun gratis.

Ketika kegiatan pembelajaran daring tentunya siswa perlu penerapan pembelajaran yang menarik, menyenangkan, tidak membosankan serta selalu ingin adanya perubahan maupun sesuatu yang baru dalam setiap kegiatan belajar mengajar. Untuk mengatasi kejenuhan siswa dalam pembelajaran daring SD Islam Kreatif Mutiara Anak Sholeh telah menerapkan sekolah penggerak dan juga menerapkan kurikulum yang memerdekakan siswa yang siswa bebas belajar, guru tidak membatasi siswa dalam kegiatan pembelajaran daring ini. Khususnya siswa dibebaskan mengasah pemikirannya dan mau mengeksplor hal-hal baru yang ingin diketahuinya. Selain menerapkan sekolah penggerak dan kurikulum yang memerdekakan siswa, SD Islam Kreatif Mutiara Anak Sholeh juga menerapkan beberapa media quiz interaktif diantaranya quizizz, kahoot, powtoon, educandy, dsb.

Aktivitas bermain ialah sesuatau aktivitas yang menyenangkan dan mengasyikkan. Aktivitas bermain memiliki tujuan sebagai pendorong dalam perkembangan anak. Anak akan terdorong untuk memperlihatkan keterampilan dan kemampuannya baik dari segi kognitif maupun yang lainnya. Dengan mengaplikasikan media permainan quiz interaktif dapat memicu meningkatnya semangat dan antusias dalam mengikuti pembelajaran daring. Dengan pengaplikasian media permainan quiz 
interaktif banyak siswa yang menganggap materi yang diajarkan mudah dimengerti, dipahami karena kebanyakan dari siswa menganggap bukan seperti belajar tapi seperti bermain. Jadi, SD Islam Kreatif Mutiara Anak Sholeh menerpakan bermain sambil belajar.

Dalam praktek pengajarannya, ustadz dan ustadzah SD Islam Kreatif Mutiara Anak Sholeh tidak suka memberikan pembelajaran daring menggunakan platform whatsapp karena dianggap kurang efektif dan efisien. Sepemikiran dengan Elianur mengatakan bahwa menggunakan whatsapp dalam pembelajaran daring dapat memicu ketidakefektifan dengan beberapa alasan diantaranya, (1) Penjelasan materi dalam pembelajaran kurang jelas, (2) Fokus belajar siswa kurang terarah, (3) Interaksi yang terjalin antar guru dan siswa kurang baik, (4) Guru kesulitan mengetahui keberhasilan siswa dalam mengikuti kegiatan pembelajaranan (Elianur et al., 2020, pp. 37-45). Ustadz dan ustadzah SD Islam Kreatif Mutiara Anak Sholeh sepakat untuk mengaplikasikan media pembelajaran yang lebih interaktif yaitu quizizz.

Quizizz merupakan salah satu bentuk pembaharuan dalam pembelajaran sebagai media latihan soal siswa. Quizizz dapat diartikan sebagai suatu media digital yang mendukung keberlangsungan pembelajaran daring yang sifatnya interaktif dan menyenangkan. Sejalan dengan pemikiran Priyanti dkk mengatakan bahwa quizizz merupakan suatu media digital yang dipergunakan oleh siswa dalam memahami susatu bacaan maupun materi dengan cara menyenangkan (Priyanti et al., 2019, pp. 71-80). Quizizz telah diaplikasikan kedalam kegiatan pembelajaran SD Islam Kreatif Mutiara Anak Sholeh terbilang kurang lebih 1 tahun semenjak pembelajaran dilaksanakan secara daring. Seluruh ustadz dan utadzah mengatakan bahwa denagn menggunakan media pembelajaran dapat membantu meningkatkan pemahaman siswa serta kegiatan pembelajaran menjadi efektif. Untuk menanggulangi minim nya pengetahuan siswa maupun orang tua dengan media quizizz ini, ustadz dan ustadzah terlebih dahulu memberikan tutorial mengenai cara bergabung atau join, cara menggunakan media quizizz, dsb agar selanjutnya siswa dan orang tua paham mengenai penggunaan media quizizz, cara bergabung dalam media quizizz. Bersyukurnya fasilitas yang di miliki oleh guru maupun siswa Sd Islam Kreatif Mutiara Anak Sholeh sudah sesuai dan mendukung penggunaan media quizizz.

Tak lupa juga ustadzah winda mengatakan bahwa media quizizz dapat dengan mudah dibuat oleh guru melalui beberapa tahapan diantaranya, (1) Buka google chrome. (2) search dan ketik www.quizizz.com untuk login maupun sign up. (3) Klik teacher untuk login sebagai guru. (4) Daftar dan masukkan data diri atau identitas. (5) Pilih dan klik create new quiz. (6) Masukkan dan buatkan materi serta soal-soal dari materi yang akan dipelajari. (7) Jika selesai membuat materi dan soal klik save. (8) Kemudian pilih dan klik homework untuk tugas atau PR (pekerjaan rumah) dan pilih dan klik play live untuk dikerjakan secara live melalui zoom meeting secara berkelompok. (9) Atur jam dan tanggal melalui procced. (10) share dan bagikan code bergabung quizizz kepada seluruh siswa.

Dalam kegiatan wawancara terstruktur, Ustadzah Muhfidatul Winda Hidayah mengatakan bahwa setiap bahan ajar, metode pengajaran, maupun media pembelajaran tentunya memiliki kelebihan dan kekurangan. Kelebihan media quizizz dalam kegiatan pembelajaran diantaranya, (1) kegiatan pembelajaran terhindar dari kata membosankan. (2) Mudah diakses oleh siapapun dan kapanpun. (3) sebagai bahan evaluasi kegiatan 
pembelajaran. (4) Tampilan yang diberikan media quizizz sangat berwarna, segar, dan menarik sehingga memberikan kesan menyenangkan. (5) Terdapat musik yang dapat mendukung dan meningkatkan semangat siswa dalam kegiatan pembelajaran. (6) Di dalam media quizizz terdapat fitur live secara berkelompok maupun tugas atau pekerjaan rumah. (7) Media quizizz memiliki beberapa fitur mengenai penggunaan jenis soal diantaranya pilihan ganda, isi bagian yang rumpang, survei, centang kotak, esai. (8) Siswa dengan mudah mengetahui letak benar dan salah dari jawabannya. Sedangkan mengenai kekurangan dari media quizizz diantaranya, (1) Kurang adanya fitur yang mendukung untuk menampilkan audio maupun video, jadi ketika ingin menampilkan audio maupun video pada media quizizz harus mengubahnya ke media quizizz yang berbayar. (2) Tidak mempunyai game board.

Berdasarkan hasil survei mengenai persepsi siswa tentang penggunaan media quizizz dalam pembelajaran daring di SD Islam Kreatif Mutiara Anak Sholeh, berikut ini adalah data-data mengenai persepsi siswa melalui penyebaran google form.

\section{Tabel 1 Persepsi Siswa mengenai Penggunaan Media Quizizz dalam Pembelajaran Daring}

\begin{tabular}{lll}
\hline Keterangan & Persentase \\
\hline $\begin{array}{l}\text { Siswa merasa tertarik dan senang saat pembelajaran daring } \\
\text { menggunakan media quizizz }\end{array}$ & $100 \%$ \\
\hline $\begin{array}{l}\text { Siswa termotivasi untuk belajar lebih giat lagi setelah } \\
\text { mengaplikasikan media quizizz dalam pembelajaran daring }\end{array}$ & $100 \%$ \\
\hline $\begin{array}{l}\text { Siswa merasa mendapatkan pengalaman baru setelah menggunakan } \\
\text { media quizizz dalam pembelajaran daring }\end{array}$ & $100 \%$ \\
\hline $\begin{array}{l}\text { Siswa lebih mudah memahami materi saat menggunakan media } \\
\text { quizizz dalam pembelajaran daring }\end{array}$ & $100 \%$ \\
\hline $\begin{array}{l}\text { Siswa memperoleh hasil belajar atau score tinggi saat mengerjakan } \\
\text { latihan-latihan menggunakan media quizizz }\end{array}$ & $91,3 \%$ \\
\hline $\begin{array}{l}\text { Siswa menjadi lebih aktif dan ikut serta dalam menjawab dan } \\
\text { bertanya mengenai materi, soal yang di tampilkan oleh guru } \\
\text { menggunakan media quizizz }\end{array}$ & \\
\hline
\end{tabular}

Sejalan dengan perkataan salah satu guru di sekolah tersebut, beliau berkata bahwa media quizizz apabila digunakan sebagai pendukung dalam kegiatan pembelajaran sangat berpengaruh terhadap kejenuhan siswa. Dengan adanya media quizizz mampu mengatasi kejenuhan siswa saat kegiatan pembelajaran dimulai dengan menerapkan media quizizz secara live melalui zoom meeting. Antusias siswa dalam mengikuti kegiatan pembelajaran terlihat jelas keetika menerapkan media quizizz ini serta memicu terciptanya pembelajaran yang mengasyikkan dan seru. Selain itu siswa akan lebih bersemangat dan lebih antusias lagi saat ada media-media pembelajaran interktif yang lebih bervariasi dalam kegiatan pembelajaran daring, kata Ustadzah Winda dalam kegiatan wawancara.

Selain dapat mengatasi kejenuhan siswa media pembelajaran juga dapat memicu timbulnya keinginan serta minat yang tinggi dalam mengikuti kegiatan pembelajaran. Minat belajar siswa dapat diukur melalui pencapaian minat siswa dalam pembelajaran atau biasa disebut dengan indikator minat. Ricardo dkk mengatakan terdapat beberapa 
indikator minat diantaranya (1) timbul rasa tertarik untuk mengikuti kegiatan pembelajaran (2) terlibat aktif dalam kegiatan pembelajaran (3) memiliki tingkat konsentrasi yang tinggi (4) lebih memperhatikan materi yang diajarkan daa dijelaskan oleh guru (Ricardo \& Meilani, 2017, pp. 190-192). Minat belajar yang baik tentu akan menghasilkan hasil belajar yang baik. Penggunaan media quizizz juga mempengaruhi meningkatnya hasil belajar siswa. Hasil belajar merupakan suatu penentu yang dapat diraih oleh siswa setelah melaksanakan kegiatan belajar mengajar yang telah disusun oleh guru pada suatu lembaga pendidikan (Dwijayani, 2019, p. 175). Sedangkan menurut teori Taksonomi bloom mengatakan bahwa hasil belajar dapat diraih melalui tiga karakterisik yaitu ranah sikap, ranah pengetahuan, dan ranah keterampilan. Ranah sikap memiliki lima aspek diantaranya, (1) Receiving atau penerimaan (2) Responding atau menjawab (3) Valuing atau penilaian (4) Organization atau mengelola (5) Karakteristik. Sedangkan ranah pengetahuan terdiri dari enam aspek diantaranya, (1) Pengetahuan (2) Pemahaman (3) Penerapan (4) Analisis (5) Sintesis (6) Evaluasi. Selain itu, hasil belajar juga dapat dicapai melalui ranah keterampilan diantaranya (1) Gerakan refleks meniru (2) Pengalamiahan (3) Memanipulasi (4) Artikulasi (Almutairi et al., 2020, pp. 1-5).

Jadi, hasil belajar merupakan penilaian yang diberikan oleh guru kepada siswa setelah ikut serta dalam kegiatan pembelajaran dengan menilai sikap, pengetahuan, keterampilan yang ditandai dengan berubahnya tingkah laku pada diri siswa. Dalam media quizizz hasil belajar siswa dapat dilihat melalui leader board yang menunjukkan tingkat siswa sesuai dengan score yang diperoleh saat menggunakan media quizizz. Antara siswa yang satu dengan yang lainnya dapat dengan mudah melihat score serta peringkatnya. Dengan begitu, dapat memicu semangat siswa untuk memahami materi lebih mendalam agar score yang diperoleh lebih baik dari siswa yang lainnya. Selain itu seluruh siswa SD Islam Kreatif Mutiara Anak Sholeh juga lebih semangat untuk memahami materi sebelum memainkan media quizizz serta dapat meningkatkan minat siswa dalam belajar dan mempelajarai terlebih dahulu matari yang akan dipelajari pada pertemuan selanjutnya. Terdapat juga fitur tambahan yang dapat diaktifkan oleh guru yang mana dengan fitur tersebut dapat dipergunakan untuk meningkatkan minat maupun daya tarik serta mencuptakan keseruan dalam kegiatan pembelajaran daring, seperti memberikan reward atau diperbolehkan replay soal yang salah jika berhasil konsisten menjawab beberapa soal dengan benar.

Dalam penggunaan aplikasi media quizziz di SD Islam Kreatif Mutiara Anak Sholeh terlihat siswa dan siswinya memiliki antusias serta semangat yang tinggi. Sejalan dengan yang dikatakan oleh ustadzah winda, materi apapun apabila pengaplikasiannya menggunakan media atau game pasti semangat siswa dan siswi SD Islam Kreatif Mutiara Anak Sholeh itu luar biasa. Sehingga dengan pengaplikasian media atau game tersebut membuat siswa menjadi aktif dalam menjawab maupun bertanya terkait materi yang sedang dipelajari. Hal tersebut juga dapat memicu terciptanya suasana pembelajaran yang hidup dan bermakna karena guru dan siswa dapat berinteraksi dengan baik. Terlebih lagi aplikasi media quizziz ini mudah diakses melalui laptop maupun handphone serta bisa digunakan beberapa kali, sehingga memudahkan siswa dalam pengerjaannya. Walaupun terkadang dalam pembelajaran melalui media game quizziz tidak selalu berjalan lancar. Hal tersebut sering kali disebabkan adanya beberapa kendala. Kendala secara umum yang sering terjadi ketika 
penggunaan media game quizziz ini dikarenakan masalah sinyal. Dalam mengatasi kendala tersebut guru memberikan keringanan serta solusi kepada siswa yang mengalami koneksi buruk yaitu dengan mengkonfirmasi kepada guru atau grup kelas siswa sehingga dapat konpensasi waktu dalam mengerjakan latihan soal melalui media quizizz tersebut sampai sinyalnya kembali normal.

\section{KESIMPULAN}

Upaya dalam pencegahan wabah covid-19 di lingkungan sekolah dengan melaksanakan pembelajaran secara daring atau dalam jaringan. Kegiatan pembelajaran daring yang membosanakan dan dalam rentang waktu yang lama memicu munculnya kejenuhan baik dari segi pandangan siswa, guru, maupun orang tua. Oleh karena itu, untuk menanggulangi rasa jenuh yang timbul pada diri setiap siswa dalam pembelajaran daring hendaknya guru lebih berupaya meningkatkan kinerjanya serta mampu berinovasi dalam mengemas pembelajaran. Hal tersebut bertujuan agar siswa merasa tidak jenuh, tidak membosankan, menurunnya minat, menurunnya motivasi mengikuti kegiatan pembelajaran, serta menurunya keteguhan dalam belajar secara daring. Adanya berbagai macam jenis media online yang mendukung keberlangsungan pembelajaran daring yang mana sejalan dengan perubahan revolusi industri 4.0, hal tersebut dapat meningkatkan motivasi, minat siswa dalam kegiatan pembelajaran serta terkemas lebih menyenangkan serta lihai dalam memadu padankan metode dan media pembelajaran salah satunya dengan penggunaan media quizizz. Dengan begitu, permasalahan diatas dapat teratasi dengan tujuan untuk mengetahui bagaimana solusi dari pembelajaran daring yang lebih menyenangkan menggunakan media quizizz.

Berdasarkan hasil penelitian, peneliti menarik kesimpulan bahwa media quizizz. yang digunakan oleh guru dalam mendukung pembelajaran daring di masa pandemi covid-19 mampu mengatasi kejenuhan siswa SD Islam Kreatif Mutiara Anak Sholeh. Terlihat dari hasil survei persepsi siswa mengenai penggunaan media quizizz ini dengan prosentase, (1) Siswa merasa tertarik dan senang saat pembelajaran daring menggunakan media quizizz sebesar $100 \%$ (2) Siswa termotivasi untuk belajar lebih giat lagi setelah mengaplikasikan media quizizz dalam pembelajaran daring sebesar $100 \%$ (3) Siswa merasa mendapatkan pengalaman baru setelah menggunakan media quizizz dalam pembelajaran daring sebesar $100 \%$ (4) Siswa lebih mudah memahami materi saat menggunakan media quizizz dalam pembelajaran daring sebesar $100 \%$ (5) Siswa memperoleh hasil belajar atau score tinggi saat mengerjakan latihan-latihan menggunakan media quizizz sebesar 91,3\% (6) Siswa menjadi lebih aktif dan ikut serta dalam menjawab dan bertanya menegani materi, soal yang di tampilkan oleh guru menggunakan media quizizz sebesar 95,7\% Selain itu siswa siswi SD Islam Kreatif Mutiara Anak Sholeh menganggap media quizizz ini mudah dalam pengoperasiannya dan tidak membingungkan. Hal ini dapat dijadikan sebagai tolak ukur bahwa berinovasi serta mengaplikasikan media pembelajaran online adalah suatu hal yang harus diterapkan dalam pembelajaran daring dengan tujuan agar pembelajaran daring tetap menyenangkan, efektif dan efisien meskipun terbatas oleh jarak yang jauh.

\section{DAFTAR PUSTAKA}

Almutairi, B. A., Alraggad, M. A., \& Khasawneh, M. (2020). The impact of Servant Leadership on Organizational Trust: The Mediating Role of Organizational 
Culture. European Scientific Journal ESJ, 16(16), 1-10. https://doi.org/10.19044/esj.2020.v16n16p49

Darmalaksana, W., Hambali, R. Y. A., Masrur, A., \& Muhlas. (2020). Analisis Pembelajaran Online Masa WFH Pandemic Covid-19 sebagai Tantangan Pemimpin Digital Abad 21. Karya Tulis Ilmiah (KTI) Masa Work From Home (WFH) Covid-19 UIN Sunan Gunung Djati Bandung Tahun 2020, 1(1), 1-12.

Dewi, R. P., Yosef, \& Harlina. (2017). Hubungan Antara Academic Self-Confidence Dengan Kejenuhan (Burnout) Belajar Siswa Smk Negeri 1 Indralaya Utara. Konseling Komprehensif, 4(2), 14-27.

Dwijayani, N. M. (2019). Development of circle learning media to improve student learning outcomes. Journal of Physics: Conference Series, 1321(2), 171-187. https://doi.org/10.1088/1742-6596/1321/2/022099

Irwan, I., Luthfi, Z. F., \& Waldi, A. (2019). Efektifitas Penggunaan Kahoot! untuk Meningkatkan Hasil Belajar Siswa [Effectiveness of Using Kahoot! to Improve Student Learning Outcomes]. PEDAGOGIA: Jurnal Pendidikan, 8(1), 95. https://doi.org/10.21070/pedagogia.v8i1.1866

Irwan, Soehartono, Metodologi Penelitian Sosial. (Bandung: Remaja Rosdakarya, 2008) 35

Khaira, N. A. (2018). Penerapan Teknik Self Instruction Untuk Mengurangi Kejenuhan Belajar Siswa. Jurnal Pencerahan, 4(1), 13-30.

Lam, N., Muravez, S. N., \& Boyce, R. W. (2015). A comparison of the Indian Health Service counseling technique with traditional, lecture-style counseling. In Journal of the American Pharmacists Association (Vol. 55, Issue 5). https://doi.org/10.1331/JAPhA.2015.14093

Nurdin, I. R. (2017). Penerapan Sistem Pembelajaran Jarak Jauh Berbasis Massive Open Online Course (Mooc) Di Universitas Ciputra Enterpreunership Online (UCEO). Tugas Akhir, 79. http://lib.unnes.ac.id/31063/1/1102412096.pdf

Pratiwi, W. I. (2020). Strategi Komunikasi Interpersonal Guru Dalam Pelaksanaanpembelajaran Strategi Komunikasi Interpersonal Guru Dalam Pelaksanaan Strategi Komunikasi Interpersonal Guru Dalam Pelaksanaan Pembelajaran Jarak Jauh Di Sekolah Dasar, Klaten , Jawa Tengah. Jp3Sdm, 9(2), 30-46.

Priyanti, N. W. I., Santosa, M. H., \& Dewi, K. S. (2019). Effect of Quizizz Towards the Eleventh-Grade English Students' Reading Comprehension in Mobile Learning Context. Language and Education Journal Undiksha, 2(2), 71-80. https://doi.org/10.23887/leju.v2i2.20323

Rafiuddin, R., Basri, M., \& Azis, M. (2017). Urgensi Penggunaan Media dalam Proses Pembelajaran Bagi Guru Sekolah Dasar Wilayah II Kecamatan Sanrobone Kabupaten Takalar Provinsi Sulawesi Selatan. Prosiding TEP \& PDs, 2(3), 147157.

Ricardo, R., \& Meilani, R. I. (2017). Impak Minat dan Motivasi Belajar Terhadap Hasil Belajar Siswa. Jurnal Pendidikan Manajemen Perkantoran, 2(2), 79. https://doi.org/10.17509/jpm.v2i2.8108

Rohman, Moh Agus. Kejenuhan Belajar Pada Siswa Di Sekolah Dasar Full Day School (Surabaya: UIN Sunan Ampel, 2018) 13

Sari, D. P., Putra, R. W. Y., \& Syazali, M. (2018). Pengaruh Metode Kuis Interaktif 
terhadap Kemampuan Pemecahan Masalah Matematis Mata Kuliah Trigonometri. Jurnal Pendidikan Matematika, 12(2), 63-72.

Setiawan, A., Wigati, S., \& Sulistyaningsih, D. (2019). Implementasi Media Game Edukasi Quizizz Untuk Meningkatkan Hasil Belajar Matematika Materi Sistem Persamaan Linear Tiga Variabel Kelas X Ipa 7 Sma Negeri 15 Semarang Tahun Pelajaran 2019 / 2020. Seminar Nasional Edusainstek FMIPA UNIMUS 2019 ISBN, 167-173.

Suwarsono, S. (2016). Pengantar Penelitian Kualitatif. Hari Studi Dosen Program Studi Pendidikan Matematika, https://www.usd.ac.id/fakultas/pendidikan/s2_pen_matematika/f113/etnomatematik a/Pengantar Penelitian Kualitatif - Prof. Dr. St. Suwarsono.pdf

Warsita, B. (2011). Landasan Teori dan Teknologi Informasi dalam Pengembangan Teknologi Pembelajaran. Jurnal Teknodik, 15(1), 84-96. http://jurnalteknodik.kemdikbud.go.id/index.php/Teknodik/article/view/64

Yaumi, M. (2017). RAGAM MEDIA PEMBELAJARAN: Dari Pemanfaatan Media Sederhana ke Penggunaan Multi Media. Journal of Chemical Information and Modeling, 53(9), 1689-1699. 